Int. J. Odontostomat.,

6(3):291-295, 2012.

\title{
Determination of Cellular Debris in Endodontically Treated Teeth: a Pilot Study
}

\author{
Determinación de Restos Celulares en Dientes Endodonciados: Estudio piloto
}

\author{
César Rivera ${ }^{* * * *}$; Camila Muñoz \& Iván Suazo***
}

RIVERA, C.; MUÑOZ, C. \& SUAZO, I. Determination of cellular debris in endodontically treated teeth: a pilot study. Int. J. Odontostomat., 6(3):291-295, 2012.

ABSTRACT: Previous studies indicate that dental tissues are a source of mitochondrial DNA that could be useful for human identification. The main cell in the pulpo-dentin complex is the odontoblast, whose cellular body is located on the border between the pulp and dentin and continues through cell processes. In endodontically treated teeth, pulp tissue is removed, assuming the complete elimination of cellular content and the inner third of dentin. Facing the possibility of finding teeth that were treated endodontically as the only source available for a forensic analysis, is that the objective of this study is to determine the presence of cellular debris in the dentin of teeth with root canal treatment. Twenty teeth roots obtained from 8 single and multi-rooted teeth were treated endodontically, with conventional manual technique. The samples were processed by conventional histological analysis $(\mathrm{H} \& \mathrm{E})$. In root canals endodontic cement remnants and cylinder-cubic structures resembled odontoblastic bodies were observed, but without certainty to establish its presence. This research concludes that it is not possible to determine presence of cellular debris in endodontically treated teeth using the described technique.

KEY WORDS: odontoblasts, tooth nonvital, endodontically treated tooth, root canal treatment, mitochondrial DNA.

\section{INTRODUCTION}

Teeth play an important role in identification and criminology; the uniqueness of its features and characteristics, makes them able to withstand extreme conditions and over the years, thanks to the relatively high degree of physical and chemical resistance of the structure (Pretty \& Sweet, 2001; da Silva et al., 2007).

This ability to withstand environmental changes makes pulpo-dentin complex an excellent source of mitochondrial DNA that can provide the necessary information to identify individuals in those cases which conventional methods can not be made or arranged for dental identification (Pretty \& Sweet; Malaver \& Yunis, 2003); that is because this is an extremely interesting finding in identifying the source of DNA cells.

The main cell for the pulpo-dentin complex is the odontoblast, whose cell body is located on the pulp
- dentin border and continues by cell processes extending to the middle third of the dentin, the hard tissue that provides protection to the cell (Cohen \& Burns, 2004; Carda \& Peydró, 2006; Avery \& Chiego, 2007). In endodontically treated teeth, pulp tissue is removed, assuming the complete removal of cellular material and the inner third of dentin. This assumption is added to the limited information on the penetration of chemicals used as irrigants in endodontic procedures, which ignore the degree of destruction of organic matter (Cohen \& Burns; Villena, 2001).

Because of this evidence and against the possibility of finding pieces that were treated endodontically as sole biological substrate available for forensic analysis, is that the objective of this study is to determine the presence of cellular debris in the dentin of endodontic treatment teeth, as mitochondrial DNA sources for human identification.

\footnotetext{
* Department of Basic Biomedical Sciences, Faculty of Health Sciences, University of Talca, Talca, Chile.

" Master Program in Biomedical Sciences, Oral Pathology mention, University of Talca, Talca, Chile.

${ }^{* * *}$ Faculty of Medicine, Diego Portales University, Santiago, Chile.
} 


\section{MATERIAL AND METHOD}

To conduct this study we used an experimental design. The independent variable was root canal treatment; the dependent variable was the presence of cellular debris in dentinal tubules.

Teeth. Twenty teeth roots obtained from 8 single and multi-rooted teeth from patients of different sexes were obtained from Family Health Centers of the Maule Region, Chile, and Dental Clinics of the University of Talca. The teeth were applied for the following inclusion criteria: teeth from patients between 12 and 35 years of age, permanent teeth with extraction indication which structure could be intact or decayed dentine surface post-extraction tooth with a period not exceeding one week.

Experimental Root Canal Treatment. The teeth were embedded in serum immediately after extraction, and subsequently proceeded with root canal treatment
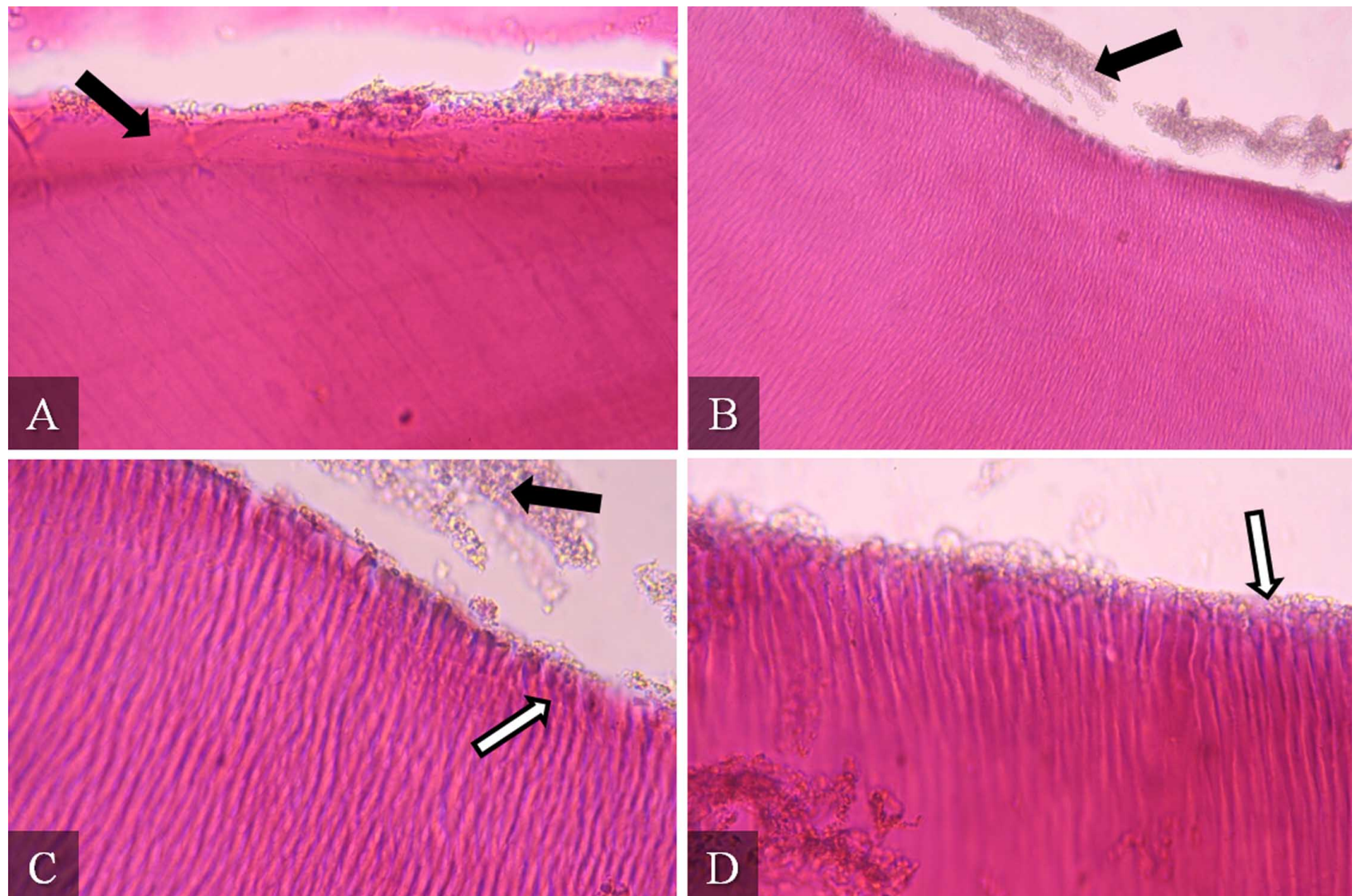

using conventional manual technique, with stainless steel hand tools, using sodium hypochlorite as irrigant $(\mathrm{NaOCl})$ and $0.5 \%$ saline, and using for endodontic sealing zinc oxide eugenol cement based and guttapercha.

Sample for conventional histopathology. Once the root canal treatment was finished, roots were separated of the crown with a carborundum disk mounted in a hand piece. The roots were sectioned by a parallel cut to the axis, and visible traces of gutta-percha and Grossman cement were removed. The samples were decalcified with $5 \%$ nitric acid to be processed by conventional histology (H\&E).

Analysis. Sixty histological sections were obtained which were observed under an Olympus CX21 Trinocular (CR) optical microscope, in order to identify the presence of cellular debris in the dentinal tubules. Representative images were taken with a Canon EOS Digital Rebel XT attached to the microscope.

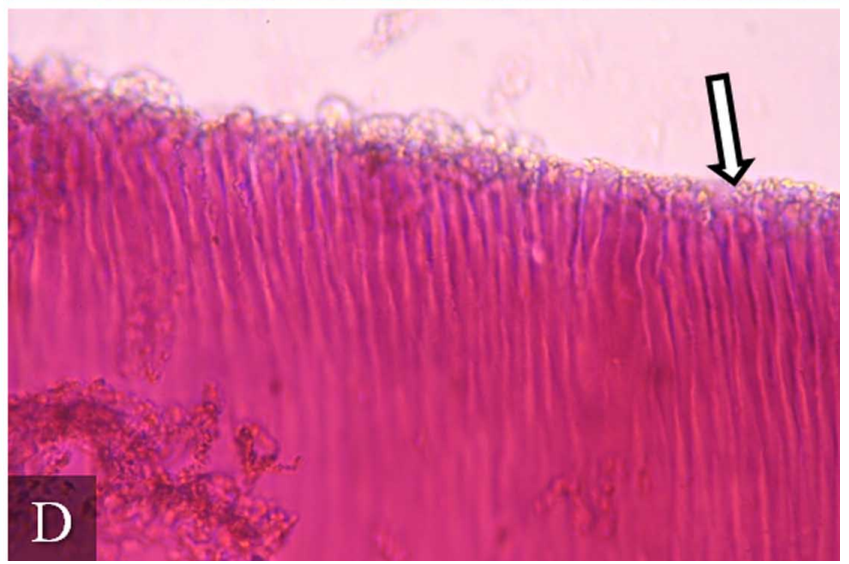

Fig. 1. Histological section of endodontically treated teeth. Remnants of endodontic cement (black arrows in A 40X, 40X B and $\mathrm{C}$ 100X) and cylinder-cubic structures on the predentin layer that appear to project into the dentinal tubules, resembling odontoblasts (white arrows in C and D 100X). There is no certainty for cell recognition and identification. 


\section{RESULTS}

It was unable to determine the presence of cellular debris in endodontically treated teeth. Under optical microscope radicular conducts of endodontically treated parts were analyzed (Fig. 1). The central area of the conduct is characterized by the absence of content (both cellular phone as endodontic filler) On the predentin layer, as normally corresponds to the odontogenic zone, we observed the presence of an amorphous, basophilic, acellular material, which corresponded to endodontic cement remnants.

The presence of cement hampered the observation of the area where the body of the odontoblasts should be allocated. From the predentin a mainly normal tubular configuration was observed, with very few areas that correspond to reparative dentin (decreased number of tubules, irregular tubules and interlaced). On the predentin layer with a 100X magnification it was observed cylindrical and cubic structures resembling odontoblasts.

\section{DISCUSSION}

The odontoblast belongs both to the pulp and dentin, as the body is located on the outside of the dental pulp and its apical pole shelters its odontoblastic process, which is located into the dentinal tubules across the dentin, originating in its route multiple collateral traces until its completion (Abramovich, 1999; Gomez \& Campos, 2009; Kohli et al., 2010).

Odontoblastic processes extend into the dentinal tubules; despite lacking most of the organelles, they contain mitochondria. In them mitochondrial DNA is found, a genetic material inherited from the mother, which is useful in forensic medicine (Malaver \& Yunis; Azlina et al., 2011).

In endodontics the complete removal of cell contents and the inner third of dentine is presumed (Cohen \& Burns; Villena; Lasala, 1992). Based on this, our study aimed to find cellular debris in the dentin of endodontically treated parts using conventional histopathological techniques observed under light microscope. As result of this research, it came out the possibility of observing any other histological cell using this technique.
The length of the odontoblast has been widely studied. It is assumed that on average this is between 1.5 and $2 \mathrm{~mm}$ (González et al., 2009). Using electronic microscopy transmission, it has been visualized occupying the predentin or near the dentin-enamel junction, both men and animals (Brännström \& Garberoglio, 1972; Grossman \& Austin, 1983; Gunji \& Kobayashi, 1983).

Another study, using the same technique of microscopy observed thick extensions in the predentin, diminishing thickness in the middle of the dentin and very thin branches late in the dentin-enamel junction (Yamada et al., 1983).

Other research found them in the middle third of dentin (Byers \& Sugaya, 1995; Goracci et al., 1999; Yoshiba et al., 2002). In an optical microscopy study, which compared the length of the odontoblast and tubules to check whether both are similar in both the crown and to the root, it was observed that the length of the tubules was always greater than that on the extensions, making them visible near the edge of tissues; but with the doubt regarding the technique used, this study concluded that the length of the odontoblastic process remains as a controversial issue (Kohli et al.).

Studies in this field are mainly carried out with samples of young, healthy teeth; so the correlation of results is discussed, because teeth are subjected to physiological processes, such as occlusion and tooth damage, abrasions, use of restorative materials, fractures and other processes, which predispose dentin permeability and dentin-pulp response which result in the retraction of odontoblastic process and apposition of dentin. This would decrease the length of the odontoblast (Mjör, 2009).

In our investigation it was not possible to discriminate between tubules and odontoblastic processes in dentin analyzed total area.

Another point is the treatment of the samples that were subjected to conventional endodontic therapy, which contemplated mechanical and chemical phase, that first removes the inner third of dentin, shortening the length of the odontoblast for the study (Cohen \& Burns; Lasala; Bronnec et al., 2009); on second place, to perform the manual root conventional technique for this experiment, sodium hypochlorite $(\mathrm{NaOCl})$, was used as irrigant, which is a potent antimicrobial agent; it has a solvent action on necrotic tissue and organic debris. 
This property is based on the high $\mathrm{pH}$ of $\mathrm{NaOCl}$ which interferes with the cytoplasmic membrane integrity, with irreversible enzyme inhibition (Cohen \& Burns). The penetration capability that has the $\mathrm{NaOCl}$ is related to its concentration: $1 \%$ penetrates 100 microns into the dentinal tubules, $2.5 \%$ up to 220 microns and 350 microns penetrates 5.25\% (BarattoFilho et al., 2004; Lahoud \& Galvez, 2006). The $\mathrm{NaOCl}$ destructive potential could explain the difficulty encountered in trying to distinguish remaining odontoblasts after pulp therapy on histologically analysis.

Malaver \& Yunis analyzed different dental tissues as source of DNA for forensic studies, obtained from teeth without any pulpar therapies. Dentin given enough mitochondrial DNA for human identification research; in this tissue enough cellular debris containing odontoblast as genetic material can be found justifying the pursuit of this material in other material for further studies.

Therefore, it is suggested to advance further studies with higher resolution microscopy and more complex techniques, such as immunohistochemistry, using specific markers for cell membranes or electronic microscopy to obtain more detailed images of the membrane or cellular organelles (De Robertis \& Hib, 2004; Ross \& Pawlina, 2007), and thereby answer the research question posed in this study which is to demonstrate through histological analyses, the presence of cellular debris in endodontically treated teeth.

ACKNOWLEDGEMENTS. The authors acknowledge the support of Alfredo Espinoza Arcos.

RIVERA, C.; MUÑOZ, C. \& SUAZO, I. Determinación de restos celulares en dientes endodonciados: Estudio piloto. Int. J. Odontostomat., 6(3):291-295, 2012.

RESUMEN: Estudios previos indican que los tejidos dentales son fuente de DNA mitocondrial útiles para la identificación humana. La principal célula del complejo pulpo-dentinario es el odontoblasto, cuyo cuerpo celular ubicado en el límite entre la pulpa y la dentina se continúa por prolongaciones celulares. En dientes tratados endodónticamente se extrae el tejido pulpar, presumiendo la completa eliminación del contenido celular y el tercio interno de la dentina. Frente a la posibilidad de encontrar dientes que fueron tratados endodónticamente como única fuente disponible para análisis forense, es que el objetivo de este estudio es determinar la presencia de restos celulares en la dentina de dientes con tratamiento de canales radiculares. 20 raíces dentarias obtenidas de 8 dientes uni y multirradiculares, fueron tratadas endodónticamente con terapia manual convencional. Las muestras fueron procesadas mediante análisis histológico convencional (H\&E). En los canales radiculares se observaron restos de cemento endodóntico y estructuras cilindro-cúbicas que asemejaron a cuerpos de odontoblastos, sin poder establecer con certeza su presencia. En esta investigación se concluye que no es posible determinar mediante la técnica utilizada la presencia de restos celulares en dientes tratados endodónticamente.

PALABRAS CLAVE: odontoblastos, restos celulares, tratamiento canales radiculares, DNA mitocondrial

\section{REFERENCES}

Abramovich, A. Histología y embriología dentaria. $2^{a}$ ed. Buenos Aires, Panamericana, 1999.

Avery, J. \& Chiego, D. Principios de Histología y Embriología Bucal. $3^{\text {a }}$ ed. Madrid, Elsevier, 2007.

Azlina, A.; Zurairah, B.; Ros, S. M.; Idah, M. K. \& Rani, S. A. Extraction of mitochondrial DNA from tooth dentin: application of two techniques. Arch. Orofac. Sci., 6(1):914, 2011.

Baratto-Filho, F.; de Carvalho, J. R. Jr.; Fariniuk, L. F.; SousaNeto, M. D.; Pécora, J. D. \& da Cruz-Filho, A. M. Morphometric analysis of the effectiveness of different concentrations of sodium hypochlorite associated with rotary instrumentation for root canal cleaning. Braz. Dent. J., 15(1):36-40, 2004.
Brännström, M. \& Garberoglio, R. The dentinal tubules and theodontoblast processes. A Scanning Electron Microscopic study. Acta Odontol. Scand., 30(3):291-311, 1972.

Bronnec, F.; Bouillaguet, S. \& Machtou, P. Ex-vivo assessment of irrigant penetration and renewal during the cleaning and shaping of root canals: a digital subtraction radiographic study. Int. Endod. J., 43(4):27582, 2009.

Byers, M. R. \& Sugaya, A. Odontoblast Processes in dentin revealed by fluorescent Di-I'. J. Histochem. Cytochem., 43(2):159-68, 1995.

Carda, C. \& Peydró, A. Ultraestructural patterns of human dentinal tubules, odontoblast processes and nerve fibres. Tissue Cell, 38(2):141-50, 2006. 
Cohen, S. \& Burns, R. Vías de la Pulpa. $8^{a}$ ed. Madrid, Elsevier, 2004.

da Silva, R. H.; Sales-Peres, A.; de Oliveira, R. N.; de Oliveira, F. T. \& Sales-Peres, S. H. Use of DNA Technology in Forensic Dentistry. J. Appl. Oral Sci., 15(3):156-61, 2007.

De Robertis, E. \& Hib, J. Fundamentos de Biología Celular y Molecular De Robertis. $4^{\text {a }}$ ed. Buenos Aires, El Ateneo, 2004.

Gómez, M. \& Campos, A. Histología, Embriología e Ingeniería Tisular Bucodental. $3^{\mathrm{a}}$ ed. Buenos Aires, Panamericana, 2009.

González, G.; Liñan, M.; Ortiz, M.; Ortiz, G.; del Real, A. \& Guerrero, G. Estudio Comparativo in vitro de tres acondicionadores de dentina para evaluar apertura de los túbulos dentinarios en conductos radiculares. Rev. Odont. Mex., 13(4):217-23, 2009.

Goracci, G.; Mori, G. \& Baldi, M. Terminal end of the humanodontoblast process: a study using SEM and confocal microscopy. Clin. Oral Investig., 3(3):126-32, 1999.

Grossman, E. S. \& Austin, J. C. Scanning Electron Microscope observations on the tubule content of freeze-fractured peripheral vervet monkey dentine (Cercopithecus pygerythrus). Arch. Oral Biol., 28(3):279-81, 1983.

Gunji, T. \& Kobayashi, S. Distribution and organization of odontoblast processes in human dentine. Arch. Histol. Jpn., 46(2):213-9, 1983.

Kohli, A.; Garcia, G.; Pezzotto, S. M. \& Poletto, L. Medición comparada de Procesos Odontoblásticos y Canalículos Dentinarios. Int. J. Morphol., 28(1):99-103, 2010.

Lahoud, V. \& Galvez, L. Irrigación endodóntica con el uso de hipoclorito de sodio. Odontol Sanmarquina, 9(1):2830, 2006.

Lasala, A. Endodoncia. 4ª ed. Barcelona, Salvat, 1992.

Malaver, P. C. \& Yunis, J. J. Different Dental Tissues as Source of DNA for Human Identification in Forensic Cases. Croat. Med. J., 44(3):306-9, 2003.

Mjör, I. A. Dentin permeability: The basis for understanding pulp reactions and adhesive technology. Braz. Dent. J., 20(1):3-16, 2009.

Pretty, I. A. \& Sweet, D. A look at forensic dentistry - Part 1: The role of teeth in the determination of human identity. Br. Dent. J., 190(7):359-66, 2001.
Ross, M. \& Pawlina, W. Histología Texto y Atlas color con Biología Celular y Molecular. $5^{\text {a }}$ ed. Madrid, Panamericana, 2007.

Villena, H. Terapia Pulpar. Lima, Universidad Peruana Cayetano Heredia, 2001.

Yamada, T.; Nakamura, K.; Iwaku, M. \& Fusayama, T. The extent of the odontoblast process in normal and carious human dentine. J. Dent. Res., 62(7):798-802, 1983.

Yoshiba, K.; Yoshiba, N.; Ejiri, S.; Iwaku, M. \& Ozawa, H. Odontoblast processes in human dentin revealed by fluorescence labeling and transmission electron microscopy. Histochem. Cell Biol., 118(3):205-12, 2002.

Correspondence to:

César Andrés Rivera Martínez

Cirujano Dentista

Universidad de Talca

Departamento de Ciencias Básicas Biomédicas

Avenida Lircay s/n, Oficina $\mathrm{N}^{\circ} 1$

Talca

CHILE

Email: contacto@cesarrivera.cl

Received: 15-03-2012

Accepted: 27-06-2012 